Research Article

\title{
Axial Loading Behaviour of Self-Compacting Concrete-Filled Thin-Walled Steel Tubular Stub Columns
}

\author{
Yunyang Wang $\mathbb{D}^{1,2}$ Lei Xiao, ${ }^{1}$ Chu Jiang, ${ }^{1}$ Yandong Jia, ${ }^{3}$ Guang Yang, ${ }^{1}$ Meng Li, ${ }^{1}$ \\ Xiangliang Tang, ${ }^{1}$ and Duo Chen ${ }^{1}$ \\ ${ }^{1}$ School of Civil and Architecture Engineering, Hunan University of Arts and Science, Changde 415000, China \\ ${ }^{2}$ Hunan Province Cooperative Innovation Center for the Construction \& Development of \\ Dongting Lake Ecological Economic Zone, Changde 415000, China \\ ${ }^{3}$ School of Civil and Architecture Engineering, Liaoning University of Technology, Jinzhou 121000, China \\ Correspondence should be addressed to Yunyang Wang; hnwangyunyang@126.com
}

Received 2 September 2020; Revised 23 December 2020; Accepted 18 January 2021; Published 31 January 2021

Academic Editor: Weerachart Tangchirapat

Copyright (c) 2021 Yunyang Wang et al. This is an open access article distributed under the Creative Commons Attribution License, which permits unrestricted use, distribution, and reproduction in any medium, provided the original work is properly cited.

\begin{abstract}
This paper presents an experimental investigation on the mechanical behaviour of self-compacting concrete-filled thin-walled steel tubular (SCCFTST) stub columns loaded in axial compression to failure. Four specimens were tested to study the effect of diameter to wall thickness $(D / t)$ ratios on the ultimate load, failure modes, and ductility of the columns. Confinement of the steel tube to concrete was also addressed. The failure modes, load versus displacement curves, and load versus strain curves were examined in detail. The experimental results showed that the ultimate state is reached when severe local buckling and rupture occurred on the steel tubes, and the concrete near the rupture has been crushed. The columns with larger $D / t$ ratios appeared more local buckling, and its location is more close to the end of the columns. The SCCFTST stub columns with smaller $D / t$ ratios show higher ultimate load and better ductility, and the steel tubes can exert higher confinement to the concrete.
\end{abstract}

\section{Introduction}

In the past several decades, the concrete-filled steel tubular columns have been used in kinds of structural engineering applications, for example, bridges, oil storage tanks, large industrial constructions, and seismic structures [1-5]. The concrete-filled steel tubular columns ideally combine the advantages of both steel tube and concrete. Compared with the reinforced concrete columns, its weight is lighter, bending stiffness is higher, and its cyclic performance is better [6]. Concrete can play a role in delaying or preventing local buckling of the steel tubes. The strength and ductility of concrete can be improved due to the confinement of steel tubes. Formwork and reinforcement are not needed during the whole construction process. The labor and cost can be saved. Steel tubes can also play a role in concrete protection. Therefore, the concrete-filled steel tubular members possess the characteristics of high strength, good ductility, fatigue, and impact resistance, etc. Schneider researched the effect of the cross-section shape of steel tube on the ultimate strength of concrete-filled steel tubular columns. He found that the steel tubes with circular cross-section offer more post-yield strength and stiffness than that of the steel tubes with rectangular cross-section [7]. Thayalan et al. investigated the behaviour of concrete-filled steel tubular columns under repeated loading. They found that the ultimate load of the columns reduced by up to 16 percent after a large number of cycle loadings [8]. Ren et al. studied the failure modes of concrete-filled steel tubular stub columns with different cross-sections, as triangular, fan-shaped, $D$ shaped, onefourth circular, and semicircular. They obtained that the columns with all kinds of cross-sections behaved in a ductile manner, and the columns show an outward local buckling near the middle height cross-section [9]. Wu et al. conducted an experiment on concrete-filled steel tubular columns with internal steel stirrups under compression. They concluded 
that the ultimate load and ductility of the columns could be considerably improved by the steel stirrups [10]. Oliveira et al. studied the confinement of steel tube to the concrete of concrete-filled steel tubular columns. They concluded that the ultimate load of the columns increased with increase concrete strength and decreased with the increase of length to diameter ratios [11].

Wall thickness of steel tubes used in concrete-filled steel tubular columns is always no less than $3 \mathrm{~mm}$. With the development of high-strength steel in recent years, thinwalled steel tubes are becoming more attractive to be used in engineering practice. Compared with normal steel tubes, the amount of steel, workload of welding, and the cost can be saved for thin-walled steel tubes. Bridge and O'Shea studied the behaviour of concrete-filled thin-walled steel tubular columns under axial compression. They found that the bearing capacity of the columns was enhanced by unbounded concrete [12]. Liang concluded that increasing the depth to thickness ratios and the levels of axial load can significantly reduce the stiffness, strength, and ductility of concrete-filled steel tubular beam-columns [13]. Liu et al. found that the concrete-filled thin-walled steel tubular columns show higher brittleness when the strength grade of concrete increases from C40 to C80. The ratios of yield loads to ultimate loads ranged from 0.6 to 0.9 [14]. There are also some applications of concrete-filled thin-walled steel tubular members in civil engineering in Japan, Australia, and other countries [15].

Self-compacting concrete can be placed and consolidated under its own weight without needing any vibration. Self-compacting concrete is cohesive enough and without segregation or bleeding. Compared with traditional concrete, self-compacting concrete possesses many advantages, as vibration is not needed, labor saved, reduced pollution caused by noise, and the filling capacity are improved [16-18]. Ouyang et al. studied the effect of mixed proportions of self-compacting concrete on behaviour of concretefilled steel tubular columns under compression. They found that the post-peak behaviour and ductility of the columns were influenced by paste volume and aggregate proportions [19]. Yu et al. studied the behaviours of self-compacting concrete-filled steel tubular columns under eccentric compression. They obtained that with increases of eccentric distance, ductility and bearing capacity of the specimens increased and decreased, respectively [20]. Yu et al. studied the behaviour of self-compacting concrete-filled steel tubular stub columns with different concrete strengths loaded under compression to failure. They concluded that the higher strength concrete leads to increase in ultimate load. The residual capacity is almost the same after failure [21]. Yu et al. concluded that the mechanism on failure modes of high strength concrete-filled steel tubular stub columns with square cross-section was a local failure. The ductility of concrete-filled steel tubular columns with high strength concrete is generally worse than that of concrete-filled steel tubular columns with normal strength concrete [22].

It can be known from the review on previous research that the experimental investigation on self-compacting concrete-filled thin-walled steel tubular columns is still insufficient. Thus, an experimental study on the mechanical properties of self-compacting concrete-filled thin-walled steel tubular (SCCFTST) stub columns under axial compression was carried out in this study. The influence of $D / t$ ratios on the mechanical behaviour of SCCFTST stub columns and confinement of the steel tube to concrete was studied.

\section{Experimental Investigation}

2.1. Design and Fabrication of Specimens. A total of 4 specimens with circular cross-sections were fabricated and tested. The parameter is the diameter to wall thickness $(D / t)$ ratios. Table 1 provides a summary of the geometric and material properties of specimens. $D$ and $t$ are the outer diameter and wall thickness of the steel tubes, respectively. $L$ is the column length. The material properties of concrete and steel tube were obtained from compression and tension tests, respectively. Detail numbering of specimens is as follows. $\mathrm{N}$ represents self-compacting concrete. $\mathrm{T} 1$ and $\mathrm{T} 2$ represent steel tube with a wall thickness of $1.2 \mathrm{~mm}$ and $3 \mathrm{~mm}$, respectively. The last number represents series numbering for specimens. Mix proportion of self-compacting concrete was listed in Table 2.

During the fabrication process of steel tubes, the smoothness of both ends' cross-section and weld quality was ensured. $15 \mathrm{~mm}$ thick square endplates were welded at each column end to ensure force uniform of concrete and steel tube. The length of the square endplates was $180 \mathrm{~mm}$. The geometric center of steel tubes and the endplates were in a vertical line. One endplate was welded to the base of a steel tube as a formwork to support the concrete during casting. Concrete was casted into a steel tube in three layers vertically until the steel tube was filled up. In order to ensure concrete filled up the steel tube, concrete was casted into a steel tube in three layers. The space in the steel tube is small. Gaps may avoid by casting concrete into steel tube in three layers. The vibration was not needed due to the self-compacting properties of the concrete. After that, specimens were put into a standard curing room. Typical photographs of the fabrication process of specimens were shown in Figure 1. For the reason that the concrete shrank over time, a layer of cement paste was filled to flush the concrete with the steel tube before the test. At last, the other endplate was welded to the top to form a complete specimen.

2.2. Material Properties. The outer diameter and two types of wall thickness of circular steel tubes were $140 \mathrm{~mm}$ and $1.2 \mathrm{~mm}$ and $3 \mathrm{~mm}$, respectively. The columns with length of $420 \mathrm{~mm}$. Strips cut from the steel tubes were tested in tension in accordance with the standard tensile test of metals [23]. The mechanical properties of steel tubes were shown in Table 1 . The average tensile yield strength of steel tubes with wall thickness of $1.2 \mathrm{~mm}$ and $3 \mathrm{~mm}$ were $345 \mathrm{MPa}$ and $358.3 \mathrm{MPa}$, respectively. The modulus of elasticity was $1.81 \times 10^{5} \mathrm{MPa}$ and $2.02 \times 10^{5} \mathrm{MPa}$, respectively. Poisson's ratio of steel tubes with a wall thickness of $1.2 \mathrm{~mm}$ and $3 \mathrm{~mm}$ was 0.3 and 0.28 , respectively. 
TABLE 1: Geometric and material properties of specimens.

\begin{tabular}{lcccccrrr}
\hline \multirow{2}{*}{ No. } & $\begin{array}{c}\mathrm{D} \times \mathrm{t} \times \mathrm{L} \\
\mathrm{mm} \times \mathrm{mm} \times \mathrm{mm}\end{array}$ & $L / D$ & $D / t$ & \multicolumn{2}{c}{ Concrete properties } & \multicolumn{2}{c}{ Steel properties } \\
& & & $f_{\mathrm{ck}}(\mathrm{MPa})$ & $E_{\mathrm{c}} /\left(\times 10^{4} \mathrm{MP}\right)$ & $F_{\mathrm{y}}(\mathrm{MPa})$ & $E_{\mathrm{s}} /\left(\times 10^{5} \mathrm{MP}\right)$ & $\mu_{\mathrm{s}}$ \\
\hline N-T1-1 & $140 \times 1.2 \times 420$ & 3.00 & 116.7 & 65.8 & 3.01 & 345.0 & 1.81 \\
N-T1-2 & $140 \times 1.2 \times 420$ & 3.00 & 116.7 & 65.8 & 3.01 & 345.0 & 0.3 \\
N-T2-1 & $140 \times 3 \times 420$ & 3.00 & 46.7 & 65.8 & 3.01 & 358.3 & 0.3 \\
N-T2-2 & $140 \times 3 \times 420$ & 3.00 & 46.7 & 65.8 & 3.01 & 358.3 & 2.02 \\
\hline
\end{tabular}

TABLE 2: Mix proportion of self-compacting concrete.

\begin{tabular}{|c|c|c|c|c|c|c|}
\hline Type of concrete & $\begin{array}{c}\text { Water } \\
\left(\mathrm{kg} \cdot \mathrm{m}^{-3}\right)\end{array}$ & $\begin{array}{l}\text { Cement } \\
\left(\mathrm{kg} \cdot \mathrm{m}^{-3}\right)\end{array}$ & $\begin{array}{l}\text { Fine aggregates } \\
\left(\mathrm{kg} \cdot \mathrm{m}^{-3}\right)\end{array}$ & $\begin{array}{c}\text { Coarse aggregates } \\
\left(\mathrm{kg} \cdot \mathrm{m}^{-3}\right)\end{array}$ & $\begin{array}{c}\text { Fly ash } \\
\left(\mathrm{kg} \cdot \mathrm{m}^{-3}\right)\end{array}$ & Superplasticizer (\%) \\
\hline Self-compacting & 198.96 & 401.47 & 836.46 & 768.5 & 122.1 & 0.4 \\
\hline
\end{tabular}

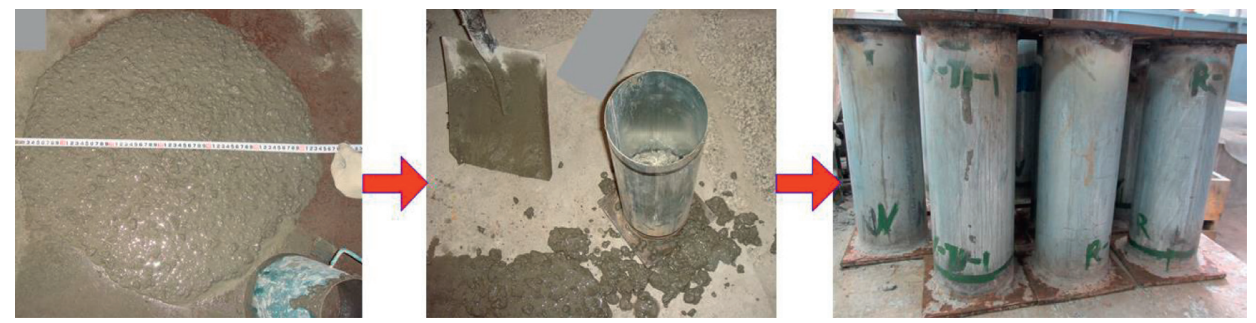

FIGURE 1: Fabrication process of specimens.

All the specimens were casted with one batch of concrete. The coarse aggregate with maximum size of $20 \mathrm{~mm}$. Six standard prisms with a dimension of $150 \mathrm{~mm} \times 150 \mathrm{~mm} \times 300 \mathrm{~mm}$ were casted and cured in conditions similar to the SCCFTST stub columns to determine the compressive strength of concrete. The concrete specimens were loaded at a constant displacement rate of $0.20 \mathrm{~mm} / \mathrm{min}$. Strain gauges were mounted on the middle height surface of the concrete prisms to obtain stress versus strain curves of concrete. The average strength $f_{\mathrm{ck}}$ and the average modulus of elasticity $E_{\mathrm{c}}$ at the time of tests were 65.8 $\mathrm{MP}$ and $3.01 \times 10^{4} \mathrm{MP}$, respectively. The mechanical properties of the concrete were shown in Table 1 .

2.3. Test Setup and Procedure. The compression tests of SCCFTST stub columns were carried out at a $5000 \mathrm{kN}$ capacity testing machine in a structural laboratory. Strains on the middle height surface of the specimen were measured by eight strain gauges. Four of the strain gauges in the axial direction and the other four in the lateral direction. Two linear variable displacement transducers measured the axial deformation. The locations and numbering of the strain gauges were shown in Figure 2. It can be seen from Figure 2 that the numbers outside the bracket represent strain gauges in the axial directions, and the numbers in the bracket represent strain gauges in the lateral directions. Sketch map of loading device and locations are shown in Figure 3. Experimental data were acquired by the computer automatically. The test setup is shown in Figure 4. To assure

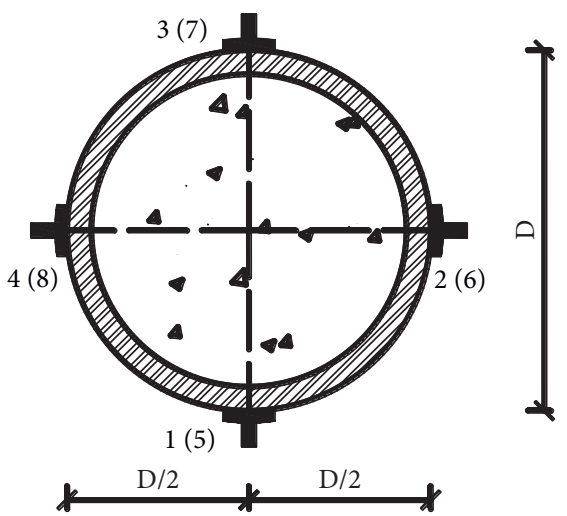

FIGURE 2: Locations and numbering of strain gauges.

compression test uniformly, preliminary tests were conducted under elastic range. The loading rate was $1 \mathrm{kN} / \mathrm{min}$ at the preliminary test stage. The position of the specimen was adjusted carefully. The adjusting procedures were based on the strains measured at the middle height surface of the specimen. Until the difference between the average values of measured strains no more than $3 \%$, the adjustment was stopped.

The loading was controlled by displacement and with a loading rate of $0.5 \mathrm{~mm} / \mathrm{min}$. The loading programs were as follows.Load was added step by step before ultimate load. Load interval was one-tenth of the estimated load bearing capacity in the elastic stage. The load interval was one-fifteenth of the estimated load bearing capacity when the load 


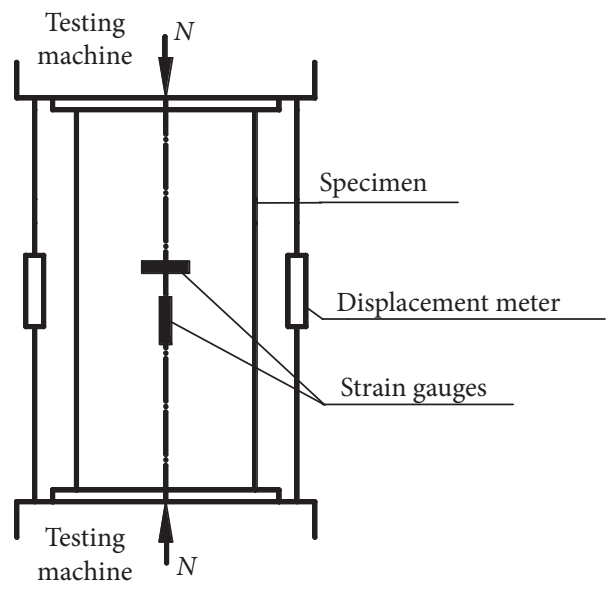

FIGURE 3: Sketch map of loading device and locations.

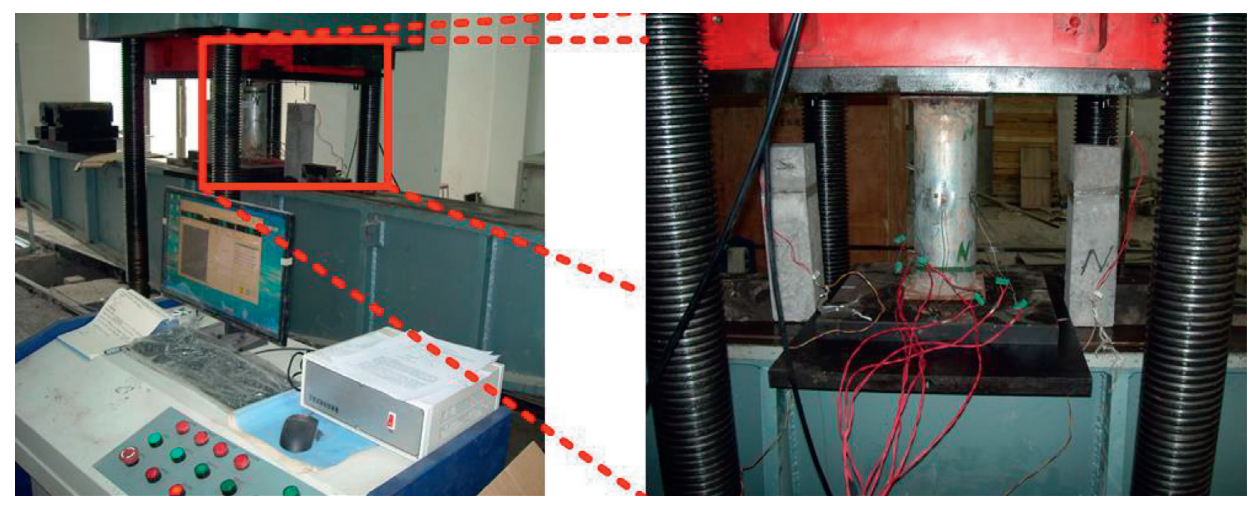

FIgURE 4: Schematic view and details for testing setup.

was increased to 70 percent of the estimated load bearing capacity. Each load interval was maintained for about 2 to 3 minutes. Loading was slow and continuous when the load approached the ultimate value. The test was stopped until the load drops to 70 percent of the ultimate value. The total test time of each specimen was about $1 \mathrm{~h}$.

\section{Experimental Results and Discussion}

3.1. Typical Behaviour of Test Specimens. The testing process of each specimen can be well controlled. As the load increased from 70 percent to 80 percent of the ultimate load, small outward local buckling occurred at about $50 \mathrm{~mm}$ below the end and top of the columns for specimens of series T1. The main characteristics of local buckling were local buckling of the steel tubes. The concrete dilation was accompanied. Local buckling becomes more obvious when the load was increased from about 90 percent to 100 percent of the ultimate load. At this time, outward buckling also occurred at one-third height and half-height of specimen surface, as shown in Figure 5.

As the load increased to 80 percent to 90 percent of the ultimate load, small outward local buckling occurred at about $70 \mathrm{~mm}$ below the end and top of the columns for specimens of series T2. Local buckling becomes more

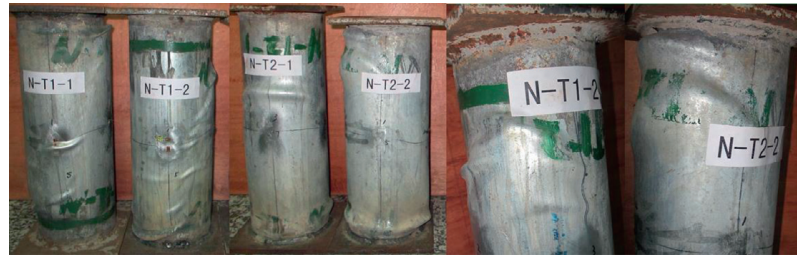

FIGURE 5: Failure modes of specimens.

obvious when the load was increased to about 100 percent of the ultimate load. At this time, outward buckling was also occurred at half height of the specimen surface, as shown in Figure 5. It can be seen from Figure 5 that more local buckling appeared on the steel tube surface for the specimens with larger $D / t$ ratios.

The steel tubes were partially ruptured when load was increased to about 100 percent of the ultimate load. It could be seen from cracks of steel tubes that the concrete was crushed. The load decreased slowly and steadily after the ultimate load for the specimens of series T2. However, the load decreased rapidly after the ultimate load for the specimens of series T1. This demonstrated the significant ductility enhancement of the SCCFTST stub columns with smaller $D / t$ ratios. The steel tubes of the SCCFTST stub 
columns with smaller $D / t$ ratios offered greater confinement to the concrete. The failure modes of the specimens were characterized as local buckling. The steel tubes were partially ruptured and the concrete near the rupture was crushed. It can be seen that the steel tubes of series T2 could exert higher confinement to the concrete than that of series T1. Therefore, the specimens of series T2 possess larger elastic-plastic deformations.

The lateral strain increased sharply when the load increased to 80 percent of the ultimate load. Partial strain gauges were stripped from the surface of the steel tube when the load increased to about 90 percent of the ultimate load. A slight squeak was from specimens when the load near the ultimate load. Local buckling was not obvious before the ultimate load. Typical failure modes were shown in Figure 5.

3.2. Load-Displacement Curves. The load versus displacement curves are shown in Figure 6. It can be seen from Figure 6 that the relationship between load and displacement is almost linearly when the load is not more than 80 percent of the ultimate load. The relationship becomes nonlinear when the load increased to 80 percent of the ultimate load. A long plastic plateau for specimens of series T2 was followed when the ultimate load is reached. However, the curves are descended suddenly when the ultimate load is reached for specimens of series T1. The load versus displacement curves for specimens of each series are similar to each other. The ultimate loads for specimens of N-T1-1, N-T1-2, N-T2-1, and N-T2-2 are $1411.6 \mathrm{kN}, 1314 \mathrm{kN}, 1637.6 \mathrm{kN}$, and $1678.6 \mathrm{kN}$, respectively. Variation coefficients of the ultimate loads on the Tl series and $\mathrm{T} 2$ series are 0.051 and 0.017 , respectively. The ultimate load and ductility of the SCCFTST stub columns increase with increases of the wall thickness of steel tubes and decrease with increases of $D / t$ ratios. The ultimate load for specimens of the $\mathrm{T} 2$ series is 21.7 percent higher than that of specimens of the T1 series. The displacement corresponding to the ultimate load for specimens of the T2 series is 40 percent higher than that of specimens of the T1 series. It seems that the plastic plateau is larger for columns with a thicker wall thickness of steel tubes. The greater the length of the plastic plateau, the better the ductility of the specimens. It is concluded that the SCCFTST stub columns with thicker wall thickness and smaller $D / t$ ratios of steel tubes exhibit better ductility.

3.3. Load-Strain Curves. The load versus axial and lateral strain curves are shown in Figure 7. It can be seen from Figure 7 that the load versus strain curves of SCCFTST stub columns with different $D / t$ ratios are similar to each other. The trends of axial strain and lateral strain vary with the load with different $D / t$ ratios that are similar to each other. The axial strain and lateral strain increase gradually with the increase of the load when the load below the ultimate value. After the ultimate load, the axial strain and lateral strain increase rapidly. The increase rate of the axial strain is faster than that of the lateral strain.

The load versus strain curves is different from the load versus displacement curves. The descending branches of load versus displacement curves corresponding to specimens

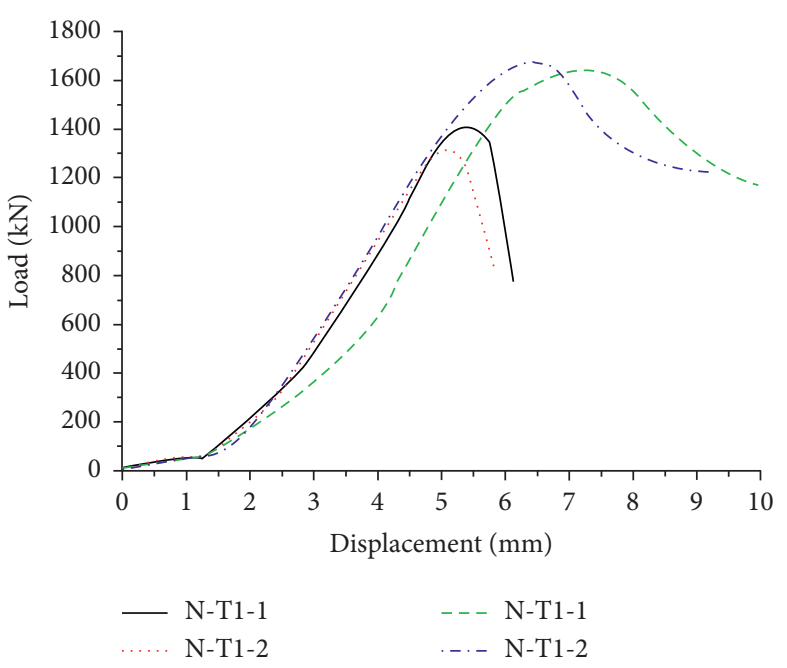

FIgURE 6: Load-displacement curves.

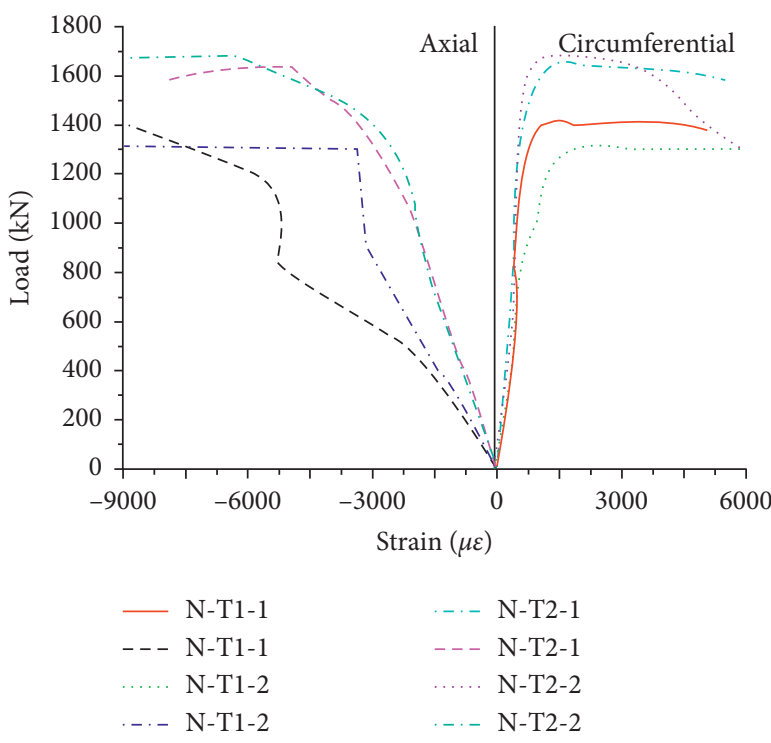

Figure 7: Load-strain curves.

with larger $D / t$ ratios are steeper after the ultimate load. The descending branches of load versus strain curves are steady and slow after the ultimate load. The reasons for this phenomenon may be due to the strains that were obtained at the middle height cross section of the columns. The strains only can represent the local deformation at the middle height cross-section of the columns. However, the load versus displacement curves reflect the overall deformation of the columns.

Before 80 percent of the ultimate load, the strain is proportional to the load. After 80 percent of the ultimate load, the load versus strain curve is nonlinear, and the increasing rate of strain is faster than that of the load. Loads of specimens N-T1-1 and N-T1-2 almost kept constant for a short time after the ultimate values. However, loads of specimens N-T2-1 and N-T2-2 are almost kept constant after the ultimate values and then decreased gradually. The 
self-compacting concrete-filled thin-walled steel tubular stub columns present good ductility due to the composite effect between the steel tube and concrete. Therefore, the bearing capacity of the columns can almost keep constant for a short time after ultimate loads.

The axial strain increases rapidly and the lateral strain increases slowly before the steel tube was yielded. The ratio of the latter to the former was from about 0.25 to 0.40 . The confinement of steel tube to concrete was not obvious at this stage. The increase rate of lateral strain was faster than that of axial strain after 80 percent of the ultimate load. The ratio of lateral strain to axial strain was more than 0.5 , even closes to 1. Both the lateral strain and axial strain increase rapidly after the ultimate load.

\section{Conclusions}

This paper presents an experimental study on the mechanical properties of SCCFTST stub columns. The typical failure modes, load versus displacement curves, load versus strain curves, and the ultimate loads of SCCFTST stub columns were obtained. The effect of $D / t$ ratios on the failure modes, ultimate loads, ductility, and confinement of the steel tube to concrete was also discussed. The main conclusions obtained by this study can be summarized as follows:

(1) The main characteristics of the failure modes of SCCFTST stub columns were local buckling. The steel tubes were partially ruptured after the ultimate load, and concrete was crushed near the rupture of steel tubes. The columns with larger $D / t$ ratios appeared more local buckling on the surface of the steel tube, and its location is more close to the end of the columns.

(2) The SCCFTST stub columns with smaller $D / t$ ratios show higher ultimate load and better ductility. The ultimate load for specimens with $D / t$ ratio of 46.7 is 21.7 percent higher than that of specimens with a $D / t$ ratio of 116.7. The displacement corresponding to the ultimate load for specimens with $D / t$ ratio of 46.7 is 40 percent higher than that of specimens with $D / t$ ratio of 116.7 .

(3) The confinement of steel tube to concrete was not obvious before load increases to 80 percent of the ultimate load. The steel tube of the SCCFTST stub columns with smaller $D / t$ ratios can exert higher confinement to the concrete, and the columns show larger elastic-plastic deformations.

\section{Data Availability}

The data used to support the findings of this study were supplied by Yunyang Wang under license and so cannot be made freely available. Requests for access to these data should be made to Yunyang Wang.

\section{Conflicts of Interest}

The authors declare that they have no conflicts of interest.

\section{Acknowledgments}

The research was supported by the Hunan Provincial Natural Science Foundation of China (grant no. 2020JJ5394), Ph.D. research startup foundation of Hunan University of Arts and Science (grant no.18BSQD28), general scientific research Project of Education Department of Hunan Province (grant no. 18C0755), and ResearchBased Learning and Innovative Experimental Program for University Students of Hunan Province (grant no. Xiang teaching [2018] 255). The authors also appreciate Professor Baoguo Han from Dalian University of Technology for his help in writing the manuscript and Professor Xuezhi Wang, Mr. Yongjun Chen, Mr. Fubo Liu and Mr. Keqiang Fang from Liaoning University of Technology for their support in the experimental work.

\section{References}

[1] E. Ellobody and B. Young, "Design and behaviour of concretefilled cold-formed stainless steel tube columns," Engineering Structures, vol. 28, no. 5, pp. 716-728, 2006.

[2] M. Elchalakani and X.-L. Zhao, "Concrete-filled cold-formed circular steel tubes subjected to variable amplitude cyclic pure bending," Engineering Structures, vol. 30, no. 2, pp. 287-299, 2008.

[3] B. Uy, "Strength of short concrete filled high strength steel box columns," Journal of Constructional Steel Research, vol. 57, no. 2, pp. 113-134, 2001.

[4] A. E. Kilpatrick and B. V. Rangan, "Tests on high-strength concrete-filled steel tubular columns[J]," Structural Journal, vol. 96, no. 2, pp. 268-274, 1999.

[5] D. Liu and W.-M. Gho, "Axial load behaviour of highstrength rectangular concrete-filled steel tubular stub columns," Thin-Walled Structures, vol. 43, no. 8, pp. 1131-1142, 2005.

[6] X. Chang, Y.-Y. Wei, and Y.-C. Yun, "Analysis of steelreinforced concrete-filled-steel tubular (SRCFST) columns under cyclic loading," Construction and Building Materials, vol. 28, no. 1, pp. 88-95, 2012.

[7] S. P. Schneider, "Axially loaded concrete-filled steel tubes," Journal of Structural Engineering, vol. 124, no. 10, pp. 11251138, 1998.

[8] P. Thayalan, T. Aly, and I. Patnaikuni, "Behaviour of concretefilled steel tubes under static and variable repeated loading," Journal of Constructional Steel Research, vol. 65, no. 4, pp. 900-908, 2009.

[9] Q.-X. Ren, L.-H. Han, D. Lam, and C. Hou, "Experiments on special-shaped CFST stub columns under axial compression," Journal of Constructional Steel Research, vol. 98, pp. 123-133, 2014.

[10] B. Wu, Q. Zhang, and G. M. Chen, "Compressive behavior of thin-walled circular steel tubular columns filled with steel stirrup-reinforced compound concrete," Engineering Structures, vol. 170, pp. 178-195, 2018.

[11] W. L. A. D. Oliveira, S. D. Nardin, A. L. H. De Cresce El Debs et al., "Influence of concrete strength and length/diameter on the axial capacity of CFT columns," Journal of Constructional Steel Research, vol. 65, no. 12, pp. 2103-2110, 2009.

[12] R. Q. Bridge and M. D O'Shea, "Behaviour of thin-walled steel box sections with or without internal restraint," Journal of Constructional Steel Research, vol. 47, no. 1-2, pp. 73-91, 1998. 
[13] Q. Q. Liang, "Strength and ductility of high strength concretefilled steel tubular beam-columns," Journal of Constructional Steel Research, vol. 65, no. 3, pp. 687-698, 2009.

[14] J. Liu, Y. Teng, Y. Zhang, X. Wang, and Y. F. Chen, “Axial stress-strain behavior of high-strength concrete confined by circular thin-walled steel tubes," Construction and Building Materials, vol. 177, pp. 366-377, 2018.

[15] M. D. O'Shea and R. Q. Bridge, "Local buckling of thin-walled circular steel sections with or without internal restraint," Journal of Constructional Steel Research, vol. 41, no. 2-3, pp. 137-157, 1997.

[16] C. J. Shi, X. Yang, Z. Yu et al., "Design and application of selfcompacting lightweight concretes," in Proceedings of the 1st International Symposium on Design, Performance and Use of Self-Consolidating Concret, Beijing, China, January 2005.

[17] C. J. Shi and Y. Z. Wu, "Mixture proportioning and properties of self-consolidating lightweight concrete containing glass powder," ACI Materials Journal, vol. 102, no. 5, p. 355, 2005.

[18] C. Shi, Z. Wu, K. Lv, and L. Wu, "A review on mixture design methods for self-compacting concrete," Construction and Building Materials, vol. 84, pp. 387-398, 2015.

[19] Y. Ouyang, J. Zeng, L. Li, and A. Kwan, "Influence of concrete mix proportions on axial performance of concrete-filled steel tubes made with self-compacting concrete," Advances in Structural Engineering, vol. 23, no. 5, pp. 835-846, 2020.

[20] F. Yu, C. Qin, S. Wang et al., "Stress-strain relationship of recycled self-compacting concrete filled steel tubular column subjected to eccentric compression," Frontiers of Structural and Civil Engineering, vol. 16, pp. 1-13, 2020.

[21] Z.-W. Yu, F.-X. Ding, and C. S. Cai, "Experimental behavior of circular concrete-filled steel tube stub columns," Journal of Constructional Steel Research, vol. 63, no. 2, pp. 165-174, 2007.

[22] Q. Yu, Z. Tao, and Y.-X. Wu, "Experimental behaviour of high performance concrete-filled steel tubular columns," ThinWalled Structures, vol. 46, no. 4, pp. 362-370, 2008.

[23] China Standard Press, GB/T 228-2010 Metallic Materials Tensile Testing-Method of Test at Room temperature, China Standard Press, Beijing, China, 2010. 